\title{
Nickel-Catalyzed Oxidative Cyclotrimerization of $\alpha$-Amino Ketones: Selective Synthesis of Pyrazoles
}

\author{
Ri-Yuan Tang, ${ }^{\text {a, }}$ Xiao-Kang Guo, ${ }^{\mathrm{b}}$ Ming Hu, ${ }^{\mathrm{a}}$ Zhi-Qiang Wang, ${ }^{\mathrm{a}} \mathrm{Jian}-\mathrm{Nan}$ Xiang, ${ }^{\text {*a }}$ Jin-Heng Li*a \\ a State Key Laboratory of Chemo/Biosensing and Chemometrics, College of Chemistry and Chemical Engineering, Hunan University, \\ Changsha 410082, P. R. of China \\ Fax+86(731)88713642; E-mail: jhli@hnu.edu.cn; E-mail: jnxiang@hnu.edu.cn \\ ${ }^{b}$ College of Chemistry and Materials Engineering, Wenzhou University, Wenzhou 325035, P. R. of China \\ Received: 18.07.2013; Accepted after revision: 22.09.2013
}

\begin{abstract}
A new strategy for the synthesis of 3-methylene-2,3-dihydro- $1 H$-pyrazoles is presented by Ni-catalyzed oxidative cyclotrimerization of $\alpha$-amino ketones. This unprecedented method allows three $\alpha$-amino ketones to undergo sequential multiple deprotonations and deamination through two $\mathrm{C}-\mathrm{C}$ bonds and one $\mathrm{N}-\mathrm{N}$ bond formation cascade.
\end{abstract}

Key words: nickel, oxidation, cyclotrimerization, $\quad \alpha$-amino ketones, pyrazoles

The functionalization of $\alpha$-amino carbonyl compounds is one of the most important tasks for biochemists or synthetic chemists because the $\alpha$-amino carbonyl motif is a ubiquitous structural component of multitudinous natural products and biomolecules. ${ }^{1,2}$ Despite the impressive progress in the field, the functionalization of $\alpha$-amino carbonyl compounds remains challenging due to the presence of some highly reactive functional groups in them, such as an active $\alpha-\mathrm{C}-\mathrm{H}$ bond, a free $\mathrm{N}-\mathrm{H}$ bond and a carbonyl group, often resulting in some competing reactions. To our knowledge, however, a method using the three functional groups for constructing new chemical bonds in one reaction has not been established.

Pyrazoles are important structural units found in numerous pharmaceuticals, agricultural chemicals and functional materials as well as valuable synthetic intermediates in organic synthesis. ${ }^{3}$ Many elegant methods have been developed for their synthesis, ${ }^{4-8}$ including, (i) the cyclocondensation of hydrazines with 1,3-dielectrophiles (1,3dicarbonyl compounds or $\alpha, \beta$-unsaturated aldehydes and ketones), ${ }^{5}$ (ii) the intermolecular 1,3-dipolar cycloaddition of diazoalkanes and nitrilimines with unsaturated compounds (such as alkenes or alkynes), ${ }^{6}$ and (iii) the introduction of substituents onto a pre-existing aromatic ring (often onto the nitrogen atom). ${ }^{7}$ However, these methods suffer from the poor reactivity, somewhat limited substrate scope, and the potential hazardousness and detonation of the substrates; moreover, regio- and chemoselectivity are usually unsatisfactory in many cases. Therefore, the development of new strategies for the synthesis of functionalized pyrazoles is highly desirable. Herein we report a novel route to prepare pyrazoles by Nicatalyzed oxidative cyclotrimerization of $\alpha$-amino arylketones wherein sequential multiple $\mathrm{C}-\mathrm{H}$ bonds cleavage, deamination and carbonyl isomerization take place to simultaneously form three $\mathrm{C}-\mathrm{C}$ bonds and one $\mathrm{N}-\mathrm{N}$ bond (Scheme 1). ${ }^{8,9}$

Our investigation began with the reaction of 1-phenyl2-(phenylamino)ethanone (1a) to optimize the reaction conditions (Table 1). Gratifyingly, substrate 1a could undergo cyclotrimerization with $\mathrm{NiCl}_{2}$ in $\mathrm{CH}_{2} \mathrm{ClCH}_{2} \mathrm{Cl}$ at $80{ }^{\circ} \mathrm{C}$, providing the desired product $2 \mathrm{a}$ in $28 \%$ yield (entry 1). Encouraged by the results a number of other Ni catalysts were examined (entries 2-6). Extensive screening revealed that $\left(\mathrm{C}_{5} \mathrm{H}_{5}\right) \mathrm{Ni}(\mathrm{II}) \mathrm{Cl}\left(\mathrm{PPh}_{3}\right)$ displayed the highest catalytic reactivity (entry 5). It is noteworthy that $\mathrm{Ni}\left(\mathrm{PPh}_{3}\right)_{4}$, a zerovalent $\mathrm{Ni}$ catalyst, also effected the reaction (entry 6). Interestingly, benzoic acid was found to favor the reaction: The yield of $\mathbf{2 a}$ was enhanced to $75 \%$ when one equivalent $\mathrm{PhCO}_{2} \mathrm{H}$ was added (entry 7). In light of the results, a series of other organic acids were subsequently evaluated (entries 8-11). While 4-cyanobenzoic acid could improve the reaction, the other acids, 4-methoxybenzoic acid, $\mathrm{AcOH}$ and $\mathrm{PivOH}$, lowered the yield slightly. Gratifyingly, good yield was still achieved under $\mathrm{O}_{2}$ atmosphere (entry 12). However, substrate 1a was found to be inert under argon atmosphere (entries 13 and 14) as well as in the absence of Ni catalysts (entry 15).
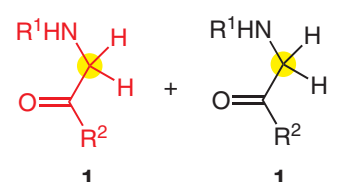

1

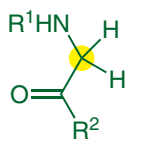

1

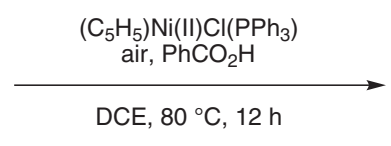

DCE, $80^{\circ} \mathrm{C}, 12 \mathrm{~h}$

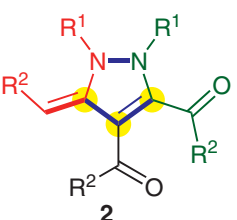

Scheme 1 Synthesis of pyrazoles

SYNLETT 2014, 25, 0064-0068

Advanced online publication: 05.11.2013

DOI: 10.1055/s-0033-1340014; Art ID: ST-2013-W0674-L

(C) Georg Thieme Verlag Stuttgart · New York 
Table 1 Screening Optimal Conditions ${ }^{\mathrm{a}}$<smiles>CC(C)CC(=O)C1=C(C(=O)c2ccccc2)C(=Cc2ccccc2)N(c2ccccc2)N1c1ccccc1</smiles>

\begin{tabular}{clll}
\hline Entry & {$[\mathrm{Ni}]$} & Additive & $\begin{array}{l}\text { Isolated } \\
\text { yield }(\%)\end{array}$ \\
\hline 1 & $\mathrm{NiCl}_{2}$ & - & 28 \\
2 & $\mathrm{NiBr}_{2}$ & - & 40 \\
3 & $\mathrm{NiCl}_{2}(\mathrm{dppe})_{2}$ & - & 29 \\
4 & $\mathrm{NiCl}_{2}(\mathrm{PCy})_{2}$ & - & 28 \\
5 & $\left(\mathrm{C}_{5} \mathrm{H}_{5}\right) \mathrm{Ni}(\mathrm{II}) \mathrm{Cl}\left(\mathrm{PPh}_{3}\right)$ & - & 59 \\
6 & $\mathrm{Ni}\left(\mathrm{PPh}_{3}\right)_{4}$ & - & 40 \\
7 & $\left(\mathrm{C}_{5} \mathrm{H}_{5}\right) \mathrm{Ni}(\mathrm{II}) \mathrm{Cl}\left(\mathrm{PPh}_{3}\right)$ & $\mathrm{PhCO}_{2} \mathrm{H}$ & 75 \\
8 & $\left(\mathrm{C}_{5} \mathrm{H}_{5}\right) \mathrm{Ni}(\mathrm{II}) \mathrm{Cl}\left(\mathrm{PPh}_{3}\right)$ & $p-\mathrm{MeOC}_{6} \mathrm{H}_{4} \mathrm{CO}_{2} \mathrm{H}$ & 51 \\
9 & $\left(\mathrm{C}_{5} \mathrm{H}_{5}\right) \mathrm{Ni}(\mathrm{II}) \mathrm{Cl}\left(\mathrm{PPh}_{3}\right)$ & $p-\mathrm{CNC}_{6} \mathrm{H}_{4} \mathrm{CO}_{2} \mathrm{H}$ & 64 \\
10 & $\left(\mathrm{C}_{5} \mathrm{H}_{5}\right) \mathrm{Ni}(\mathrm{II}) \mathrm{Cl}\left(\mathrm{PPh}_{3}\right)$ & $\mathrm{AcOH}_{3}$ & 51 \\
11 & $\left(\mathrm{C}_{5} \mathrm{H}_{5}\right) \mathrm{Ni}(\mathrm{II}) \mathrm{Cl}\left(\mathrm{PPh}_{3}\right)$ & $\mathrm{PiOH}_{3}$ & 43 \\
$12^{\mathrm{b}}$ & $\left(\mathrm{C}_{5} \mathrm{H}_{5}\right) \mathrm{Ni}(\mathrm{II}) \mathrm{Cl}\left(\mathrm{PPh}_{3}\right)$ & $\mathrm{PhCO}_{2} \mathrm{H}$ & 74 \\
$13^{\mathrm{c}}$ & $\left(\mathrm{C}_{5} \mathrm{H}_{5}\right) \mathrm{Ni}(\mathrm{II}) \mathrm{Cl}\left(\mathrm{PPh}_{3}\right)$ & $\mathrm{PhCO}_{2} \mathrm{H}$ & trace \\
$14^{\mathrm{c}}$ & $\mathrm{Ni}_{2}\left(\mathrm{PPh}_{3}\right)_{4}$ & $\mathrm{PhCO}_{2} \mathrm{H}$ & 0 \\
15 & - & $\mathrm{PhCO}_{2} \mathrm{H}$ & 0 \\
\hline & & & 0 \\
\hline
\end{tabular}

${ }^{\text {a }}$ Reaction conditions: 1a $(0.3 \mathrm{mmol})$, [Ni] (5 mol\%), additive (1 equiv) and 1,2-dichloroethane $(2 \mathrm{~mL})$ at $80^{\circ} \mathrm{C}$ for $12 \mathrm{~h}$ under air atmosphere. $\left(\mathrm{C}_{5} \mathrm{H}_{5}\right) \mathrm{Ni}(\mathrm{II}) \mathrm{Cl}\left(\mathrm{PPh}_{3}\right)=$ [chloro(cyclopentadienyl) $($ triphenylphosphine)nickel(II)]. Aniline (3a) was observed by GC-MS analysis.

${ }^{b}$ The reaction was carried out under $\mathrm{O}_{2}$ atmosphere.

${ }^{\mathrm{c}}$ The reaction was carried out under argon atmosphere.

The structure of 2a was unambiguously confirmed by the single-crystal X-ray diffraction analysis.

As shown in Scheme 2, the above cyclotrimerization protocol was found to be applicable to a diverse range of $\alpha$-amino arylketones $\mathbf{1}$ in the presence of $\left(\mathrm{C}_{5} \mathrm{H}_{5}\right) \mathrm{Ni}(\mathrm{II}) \mathrm{Cl}\left(\mathrm{PPh}_{3}\right), \mathrm{PhCO}_{2} \mathrm{H}$ and air. ${ }^{10}$ Initially, a variety of 2-(substituted arylamino)-1-phenylethanone were investigated under the optimal conditions (products $\mathbf{2} \mathbf{b}$ g): several substituents, such as $\mathrm{Me}, \mathrm{MeO}, \mathrm{Cl}$ and $\mathrm{F}$, on the aryl ring of the arylamino moiety were tolerated well. Methyl-substituted substrates $\mathbf{1 b}-\mathbf{d}$, for instance, were successfully cyclotrimerized in moderate yields, and the reactive order was found to be para $>$ meta $>$ ortho (products $\mathbf{2 b}-\mathbf{d}$ ). Importantly, functional groups $\mathrm{F}$ and $\mathrm{Cl}$ were compatible with the optimal conditions, thereby facilitating additional modifications at the halogenated positions (products $2 \mathbf{f}, \mathbf{2 g}, \mathbf{2 j}, \mathbf{2 m}, \mathbf{2 r}$ and $\mathbf{2 s}$ ). It is noteworthy that 2-amino-1-p-tolylethanones $\mathbf{1 h}-\mathbf{k}$ with an aryl group, such as $\mathrm{Ph}, 4-\mathrm{MeOC}_{6} \mathrm{H}_{4}, 4-\mathrm{ClC}_{6} \mathrm{H}_{4}$ or 2,3-dihydro- $1 H$-inden-5-yl group, on the amino moiety successfully underwent the cyclotrimerization in the presence of $\left(\mathrm{C}_{5} \mathrm{H}_{5}\right) \mathrm{Ni}(\mathrm{II}) \mathrm{Cl}\left(\mathrm{PPh}_{3}\right), \mathrm{PhCO}_{2} \mathrm{H}$ and air (products $\left.\mathbf{2 h}-\mathbf{k}\right)$.
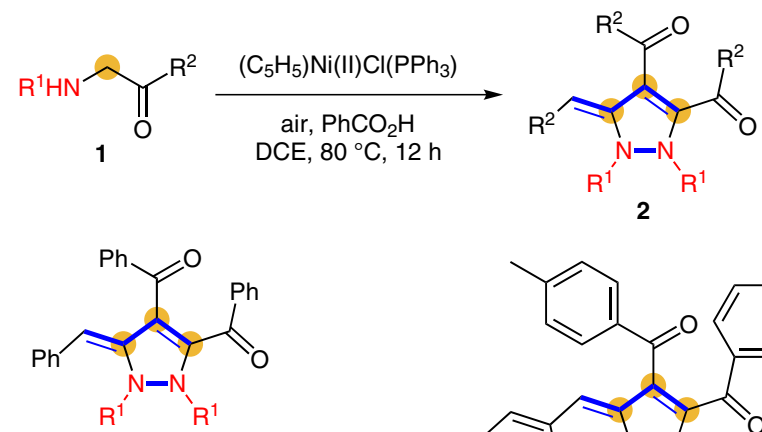

2b R ${ }^{1}=4-\mathrm{MeC}_{6} \mathrm{H}_{4}, 64 \%$

2c $\mathrm{R}^{1}=3-\mathrm{MeC}_{6} \mathrm{H}_{4}, 52 \%$

2d R ${ }^{1}=2-\mathrm{MeC}_{6} \mathrm{H}_{4}, 33 \%$

2e $\mathrm{R}^{1}=4-\mathrm{MeOC}_{6} \mathrm{H}_{4}, 50 \%$

2f $\mathrm{R}^{1}=4-\mathrm{ClC}_{6} \mathrm{H}_{4}, 68 \%$

$2 \mathrm{~g} \mathrm{R}^{1}=4-\mathrm{FC}_{6} \mathrm{H}_{4}, 56 \%$
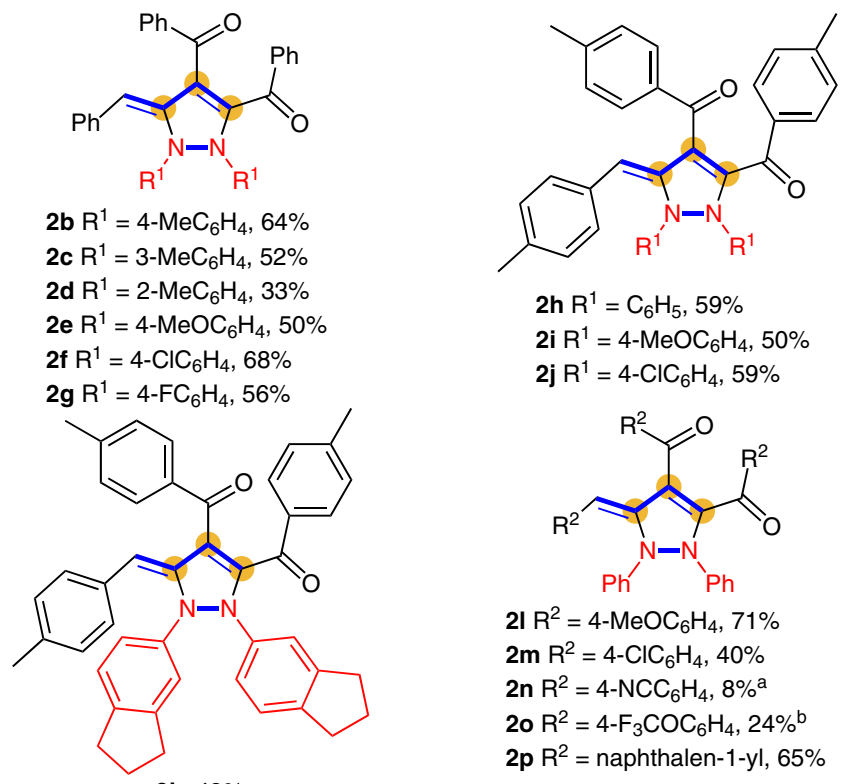

2h R $\mathrm{R}^{1}=\mathrm{C}_{6} \mathrm{H}_{5}, 59 \%$ 2i $\mathrm{R}^{1}=4-\mathrm{MeOC}_{6} \mathrm{H}_{4}, 50 \%$ 2j $\mathrm{R}^{1}=4-\mathrm{ClC}_{6} \mathrm{H}_{4}, 59 \%$

2k, $49 \%$

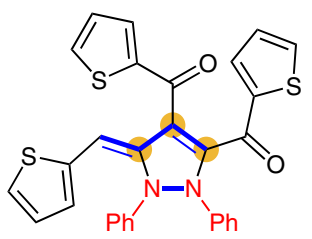

2q, $62 \%^{c}$

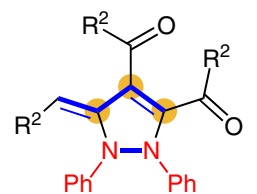

2I $\mathrm{R}^{2}=4-\mathrm{MeOC}_{6} \mathrm{H}_{4}, 71 \%$

$2 \mathrm{~m} \mathrm{R}^{2}=4-\mathrm{ClC}_{6} \mathrm{H}_{4}, 40 \%$

2n $\mathrm{R}^{2}=4-\mathrm{NCC}_{6} \mathrm{H}_{4}, 8 \% \mathrm{a}$

2o $\mathrm{R}^{2}=4-\mathrm{F}_{3} \mathrm{COC}_{6} \mathrm{H}_{4}, 24 \%$ b

$2 p R^{2}=$ naphthalen-1-yl, $65 \%$

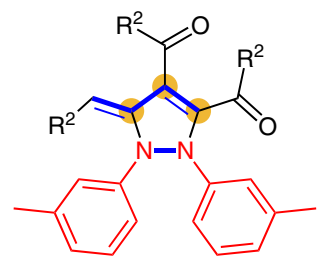

2r R $\mathrm{R}^{2}=3,4-\mathrm{Cl}_{2} \mathrm{C}_{6} \mathrm{H}_{3}, 30 \%$

2s $\mathrm{R}^{2}=4-\mathrm{FC}_{6} \mathrm{H}_{4}, 41 \%$

Scheme $2\left(\mathrm{C}_{5} \mathrm{H}_{5}\right) \mathrm{Ni}(\mathrm{II}) \mathrm{Cl}\left(\mathrm{PPh}_{3}\right)$-Catalyzed cyclotrimerization of $\alpha$ amino ketones (1) in the presence of $\mathrm{PhCOOH}$. Reagents and conditions: $1(0.3 \mathrm{mmol}),\left(\mathrm{C}_{5} \mathrm{H}_{5}\right) \mathrm{Ni}(\mathrm{II}) \mathrm{Cl}\left(\mathrm{PPh}_{3}\right)(5 \mathrm{~mol} \%)$, $\mathrm{PhCOOH}(1$ equiv) and DCE $(2 \mathrm{~mL})$ at $80{ }^{\circ} \mathrm{C}$ for $12 \mathrm{~h}$ under air atmosphere. ${ }^{\text {a }} \mathrm{A}$ dimerization/deamination product, $(E)$-2-(phenylamino)-1,4-bis(4cyanophenyl)but-2-ene-1,4-dione (4n), was obtained in 55\% yield. ${ }^{\text {b }}$ A dimerization/deamination product, (E)-2-(phenylamino)-1,4-bis[4(trifluoromethyl)phenyl]but-2-ene-1,4-dione (4o), was obtained in $49 \%$ yield. ${ }^{\mathrm{c}}$ A dimerization/deamination product, $(E)$-2-(phenylamino)-1,4-di(thiophen-2-yl)but-2-ene-1,4-dione (4q), was obtained in $24 \%$ yield.

We next set out to examine the effect of substituents on the aryl group of the 1-arylethanone moiety under the optimal conditions (products $2 \mathbf{2}-\mathbf{s}$ ). The results disclosed that a number of substituents, including $\mathrm{MeO}, \mathrm{Cl}, \mathrm{CN}$, and $\mathrm{CF}_{3}$, displayed reactivity for the reaction, but the electrondonating groups were superior to the electron-withdrawing groups (products $\mathbf{2 l}-\mathbf{0}$ ). Using substrates with the electron-withdrawing groups, however, the selectivity was 
shifted toward dimerization as the major reaction. For example, treatment of substrate $\mathbf{1 n}$ with a $\mathrm{CN}$ group with $\left(\mathrm{C}_{5} \mathrm{H}_{5}\right) \mathrm{Ni}(\mathrm{II}) \mathrm{Cl}\left(\mathrm{PPh}_{3}\right), \mathrm{PhCO}_{2} \mathrm{H}$ and air provided the corresponding dimerization product $4 \mathrm{n}$ in $55 \%$ yield. We are pleased to disclose that naphthalen-1-ylketone (1p) underwent the cyclotrimerization smoothly to offer the desired product $2 \mathbf{p}$ in $65 \%$ yield. Notably, heterocyclecontaining substrate, 2-(phenylamino)-1-(thiophen-2yl)ethanone (1q), was also suitable for the reaction, thereby making this methodology more useful for the preparation of pharmaceuticals and natural products. The reaction of diCl-substituted substrate $\mathbf{1 r}$ also proceeded smoothly, albeit in 30\% yield (product 2r). In the presence of $\left(\mathrm{C}_{5} \mathrm{H}_{6}\right) \mathrm{Ni}(\mathrm{II}) \mathrm{Cl}(\mathrm{PPh}), \mathrm{PhCOOH}$ and air, substrate 1 s with a Me group and a $\mathrm{F}$ group in different aryl rings furnished the desired product $2 \mathrm{~s}$ in moderate yield. However, ethyl 2-(phenylamino)acetate (1t), 2-aminophenylethanone (1u) and 1-(phenylamino)propan-2-one (1v) resulted in no detectable cyclotrimerization products.

The obtained pyrazole $\mathbf{2 a}$ was employed to synthesize diheterocycle 5a (equation 1 in Scheme 3). In the presence of $\mathrm{KBH}_{4}$, (Z)-3-benzylidene-1,2,4,6-tetraphenyl-2,3,4,6-<smiles>CCOC(=O)c1c(C(=O)c2ccccc2)c(-c2ccccc2)n(-c2ccccc2)c1C(=O)c1ccccc1</smiles>

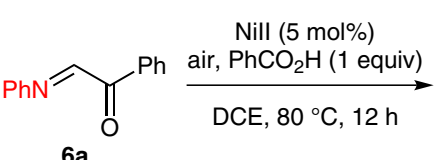
6a<smiles></smiles>

$2 a$ $\mathrm{Ni}(\mathrm{cod}): 35 \%$ $\mathrm{Ni}\left(\mathrm{PPh}_{3}\right)_{4}: 38 \%$ tetrahydro- $1 \mathrm{H}$-furo[3,4-c]pyrazole (5a) was prepared in $59 \%$ yield, which is a structural unit found in some bioactive molecules. ${ }^{11}$

During the reaction of substrate $\mathbf{1 a}$, imine $\mathbf{6 a}$ as a sideproduct was observed by in situ GC-MS analysis. ${ }^{12}$ Indeed, imine 6a could be cyclotrimerized leading to product 2a in the presence of $\mathrm{Ni}$ catalyst, such as $\left(\mathrm{C}_{5} \mathrm{H}_{5}\right) \mathrm{Ni}(\mathrm{II}) \mathrm{Cl}\left(\mathrm{PPh}_{3}\right), \mathrm{Ni}(\mathrm{cod})_{2}$ or $\mathrm{Ni}\left(\mathrm{Ph}_{3}\right)_{4}$, albeit with lower activity of the latter two Ni catalysts (equation 2 in Scheme 3), suggesting that this present cyclotrimerization reaction may proceed via the first generation of an imine intermediate $\mathbf{6 a}$.

Notably, the results in Table 1 also disclosed that without either air or Ni catalysts the cyclotrimerization reaction of substrate 1a could not take place even in the presence of $\mathrm{PhCO}_{2} \mathrm{H}$ (entries 13 and 14 in Table 1). These suggest that $\mathrm{Ni}$ complex is the real catalyst, and $\mathrm{PhCO}_{2} \mathrm{H}$ is only used to promote the reaction.

Consequently, two possible mechanisms outlined in Scheme 4 are proposed on the basis of the results described above and by the in situ HRMS analysis data (Schemes S1 and S2, and Figures S1 and S2 in Supporting Information). ${ }^{12}$ Initially, substrate 1a may proceed via two pathways, one is directly transferred into intermediate $\mathbf{A}$ with the aid of the $\mathrm{Ni}^{\mathrm{II}} /[\mathrm{O}]$ system, and the other includes the formation of imine $\mathbf{6 a}$ in the presence of $\mathrm{Ni}^{\mathrm{II}}$ and air, followed by reaction of imine $\mathbf{6 a}$ with $\mathrm{Ni}^{\mathrm{iI}}$ and $[\mathrm{O}]$ to afford the intermediate $\mathbf{A} .{ }^{11}$ Dimerization of the intermediate $\mathbf{A}$ with a molecule of imine $\mathbf{6 a}$ offers intermediate $\mathbf{B}$, followed by a hydride shift which furnishes the intermediate $\mathbf{C}$. Intermediate $\mathbf{D}$ is achieved by insertion of $\mathrm{Ni}$ into the $\mathrm{C}-\mathrm{N}$ bond in intermediate $\mathbf{C}$. The third molecule of imine 6a is used to react with intermediate $\mathbf{D}$ with the aid of acid, ${ }^{13}$ providing intermediate $\mathbf{E}$. Isomerization of intermediate $\mathbf{E}$ affords intermediate $\mathbf{F}$. Finally, reductive elimination and dehydroxylation reaction of intermediate F produces the desired product $\mathbf{2 a} .{ }^{9}$ To rule out a radical process for the current reaction, a control experiment using a radical scavenger (TEMPO) was carried out: a stoi-

Scheme 3
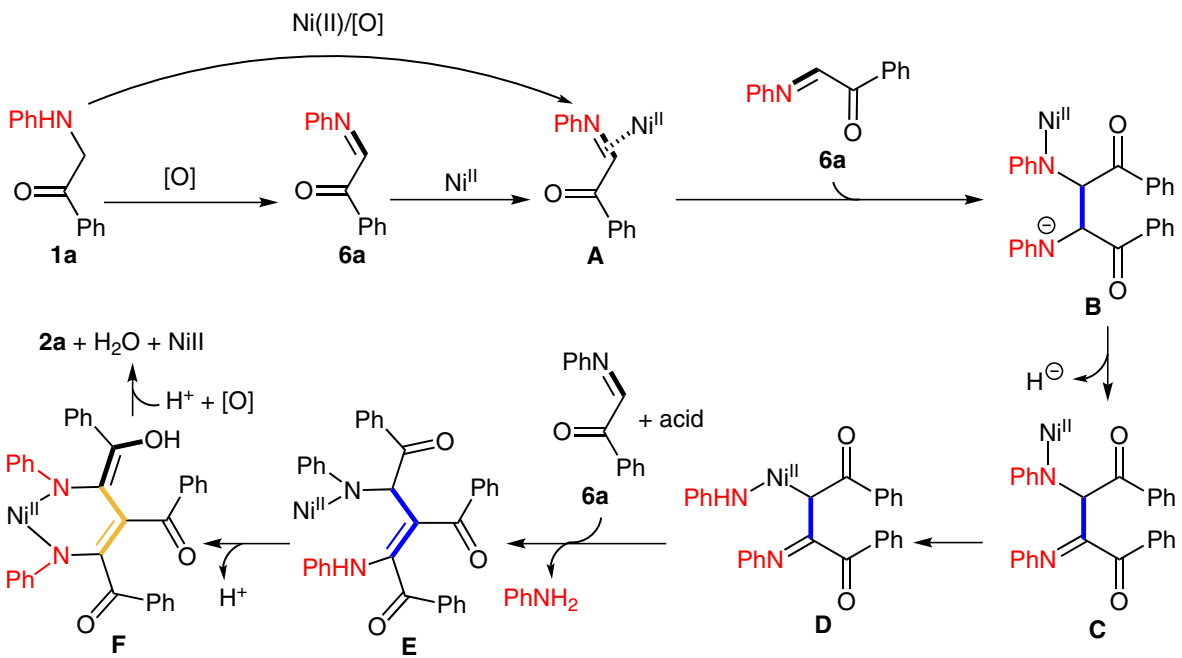

Scheme 4 Possible mechanism 
chiometric amount of TEMPO (1 equiv) had no effect on the reaction.

In summary, we have described a new route to polysubstituted 3-methylene-2,3-dihydro- $1 H$-pyrazoles via Ni-catalyzed oxidative cyclotrimerization of $\alpha$-amino carbonyl compounds, which utilizes three highly reactive functional groups, the active $\alpha-\mathrm{C}-\mathrm{H}$ bond, the free $\mathrm{N}-\mathrm{H}$ bond and the carbonyl group, in $\alpha$-amino carbonyl compounds to construct three new chemical bonds: two $\mathrm{C}-\mathrm{C}$ bonds and one $\mathrm{N}-\mathrm{N}$ bond. Importantly, this method employs accessible $\alpha$-amino carbonyl compounds as the starting materials, which facilitates introduction of the $\alpha$-amino carbonyl units into pyrazoles and makes the obtained pyrazole compounds more useful with some special complex bioactivities. Applications of this new Ni-catalyzed transformation in organic synthesis are currently underway in our laboratory.

\section{Acknowledgment}

We thank the Specialized Research Fund for the Doctoral Program of Higher Education (No. 20120161110041), Hunan Provincial Natural Science Foundation of China (No. 13JJ2018), and the Natural Science Foundation of China (No. 21172060) for financial support.

Supporting Information for this article is available online at http://www.thieme-connect.com/ejournals/toc/synlett.

\section{Reference and Notes}

(1) (a) Chemistry and Biochemistry of the Amino Acids; Barrett, G. C., Ed.; Chapman and Hall: London, 1985. (b) Williams, R. M. Synthesis of Optically Active $\alpha$-Amino Acids; Organic Chemistry Series; Pergamon: New York, 1989. (c) Ohfune, Y. Acc. Chem. Res. 1992, 25, 360. (d) Gellman, S. H. Acc. Chem. Res. 1998, 31, 173. (e) Klingler, F. D. Acc. Chem. Res. 2007, 40, 1367. (f) Concellon, J. M.; Rodriguez-Solla, H. Curr. Org. Chem. 2008, 12, 524.

(2) (a) Obrecht, D.; Altorfer, M.; Lehmann, C.; Schönholzer, P.; Müller, K. J. Org. Chem. 1996, 61, 4080. (b) Obrecht, D.; Bohdal, U.; Broger, C.; Bur, D.; Lehmann, C.; Ruffieux, R.; Schönholzer, P.; Spiegler, C.; Müller, K. Helv. Chim. Acta 1995, 78, 563. (c) Schoepp, D. D.; Jane, D. E.; Monn, J. A. Neuropharmacology 1999, 38, 1431. (d) Takahashi, A.; Naganawa, H.; Ikeda, D.; Okami, Y. Tetrahedron 1991, 47, 3621. (e) Schirlin, D.; Gerhart, F.; Hornsperger, J. M.; Hamon, M.; Wagner, J.; Jung, M. J. J. Med. Chem. 1988, 31, 30. (f) Walsh, J. J.; Metzler, D. E.; Powell, D.; Jacobson, R. A. J. Am. Chem. Soc. 1980, 102, 7136. (g) Beenen, M. A.; Weix, D. J.; Ellman, J. A. J. Am. Chem. Soc. 2006, 128 , 6304. (h) Zhao, L.; Li, C.-J. Angew. Chem. Int. Ed. 2008, 47, 7075.

(3) (a) Pal, D.; Saha, S.; Singh, S. Int. J. Pharm. Pharm. Sci. 2012, 4, 98. (b) Secci, D.; Bolasco, A.; Chimenti, P.; Carradori, S. Curr. Med. Chem. 2011, 18, 5114. (c) Bekhit, A. A.; Hymete, A.; Bekhit, A. E.-D. A.; Damtew, A.; AboulEnein, H. Y. Mini-Rev. Med. Chem. 2010, 10, 1014. (d) Viciano-Chumillas, M.; Tanase, S.; de Jongh, L. J.; Reedijk, J. Eur. J. Inorg. Chem. 2010, 3403. (e) Perez, J.; Riera, L. Eur. J. Inorg. Chem. 2009, 4913. (f) Ojwach, S. O.; Darkwa, J. Inorg. Chim. Acta 2010, 363, 1947. (g) Kumar, S.; Bawa, S.; Drabu, S.; Kumar, R.; Gupta, H. Rec. Patents on Anti-Infect. Drug Discov. 2009, 4, 154. (h) Lamberth, C.
Heterocycles 2007, 71, 1467. (i) Elguero, J.; Goya, P.; Jagerovic, N.; Silva, A. M. S. Targets Heterocycl. Syst. 2002, 6, 52. (j) Mukherjee, R. Coord. Chem. Rev. 2000, 203, 151.

(4) For reviews, see: (a) Fustero, S.; Sanchez-Rosello, M.; Barrio, P.; Simon-Fuentes, A. Chem. Rev. 2011, 111, 6984. (b) El-Saghier, A. M.; Abdel-Ghany, H.; Mohamed, M. A.; Younes, S. H. Trends Org. Chem. 2011, 15, 1. (c) Schmidt, A.; Dreger, A. Curr. Org. Chem. 2011, 15, 2897.

(d) Dadiboyena, S.; Nefzi, A. Eur. J. Med. Chem. 2011, 46, 5258. (e) Yoon, J.-Y.; Lee, S.-G.; Shin, H. Curr. Org. Chem. 2011, 15, 657. (f) Janin, Y. L. Mini-Rev. Org. Chem. 2010, 7, 314. (g) Makino, K.; Kim, H. S.; Kurasawa, Y. J. Heterocycl. Chem. 1998, 35, 489. (h) Elnagdi, M. H.; Elgemeie, G. E. H.; Abd-Elaal, F. A. E. Heterocycles $\mathbf{1 9 8 5}$ 23, 3121. (i) Kost, A. N.; Grandberg, I. I. Adv. Heterocycl. Chem. 1966, 6, 347. (j) Janin, Y. L. Chem. Rev. 2012, 112, 3924.

(5) For representative papers, see: (a) Knorr, L. Ber. 1883, 16, 2587. (b) Kempson, J. Knorr Pyrazole Synthesis, In Name Reactions in Heterocyclic Chemistry II; Li, J. J., Ed.; Wiley: New York, 2011, 317-326. (c) Huang, Y. R.;

Katzenellenbogen, J. A. Org. Lett. 2000, 2, 2833.

(d) Katritzky, A. R.; Wang, M.; Zhang, S.; Voronkov, M. V.; Steel, P. J. J. Org. Chem. 2001, 66, 6787. (e) Heller, S. T.; Natarajan, S. R. Org. Lett. 2006, 8, 2675. (f) Shen, L.; Cao, S.; Liu, N.; Wu, J.; Zhu, L.; Qian, X. Synlett 2008, 1341. (g) Fustero, S.; Roman, R.; Sanz-Cervera, J. F.; SimonFuentes, A.; Bueno, J.; Villanova, S. J. Org. Chem. 2008, 73, 8545. (h) Meng, L.; Lorsbach, B. A.; Sparks, T. C.; Fettinger, J. C.; Kurth, M. J. J. Comb. Chem. 2010, 12, 129. (i) Garcia, H.; Iborra, S.; Miranda, M. A. Heterocycles 1991, 32, 1745. (j) Grotjahn, D. B.; Van, S.; Combs, D.; Lev, D. A.; Schneider, C.; Rideout, M.; Meyer, C.; Hernandez, G.; Mejorado, L. J. Org. Chem. 2002, 67, 9200. (k) Bishop, B. C.; Brands, K. M. J.; Gibb, A. D.; Kennedy, D. J. Synthesis 2004, 43. (1) Dastrup, D. M.; Yap, A. H.; Weinreb, S. M.; Henryb, J. R.; Lechleiter, A. J. Tetrahedron 2004, 60, 901. (m) Smith, C. D.; Tchabanenko, K.; Adlington, R. M.; Baldwin, J. E. Tetrahedron Lett. 2006, 47, 3209. (n) Liu, H. L.; Jiang, H. F.; Zhang, M.; Yao, W. J.; Zhu, Q. H.; Tang, Z. Tetrahedron Lett. 2008, 49, 3805.

(6) For representative papers, see: (a) von Pechmann, H. Ber. Dtsch. Chem. Ges. 1898, 31, 2950. (b) Padwa, A. 1,3Dipolar Cycloaddition Chemistry; Vol. I; John Wiley \& Sons: New York, 1984. (c) Synthetic Applications of 1,3Dipolar Cycloaddition Chemistry Toward Heterocycles and Natural Products; Padwa, A.; Pearson, W. H., Eds.; John Wiley \& Sons: New York, 2002. (d) Mullins, R. J. Pechmann Pyrazole Synthesis in Name Reactions in Heterocyclic Chemistry II; Li, J. J., Ed.; Wiley: New York, 2011, 327-336. (e) Nakano, Y.; Hamaguchi, M.; Nagai, T.J. Org. Chem. 1989, 54, 5912. (f) Foti, F.; Grassi, G.; Risitano, F. Tetrahedron Lett. 1999, 40, 2605. (g) Aggarwal, V. K.; de Vicente, J.; Bonnert, R. V. J. Org. Chem. 2003, 68, 5381. (h) Deng, X.; Mani, N. S. Org. Lett. 2006, 8, 3505. (i) Hari, Y.; Tsuchida, S.; Sone, R.; Aoyama, T. Synthesis 2007, 3371. (j) Deng, X.; Mani, N. S. J. Org. Chem. 2008, 73, 2412. (k) Zora, M.; Kivrak, A. J. Org. Chem. 2011, 76, 9379. (l) Liang, J. T.; Deng, X.; Mani, N. S. Org. Process Res. Dev. 2011, 15, 876. (m) Xu, X.; Zavalij, P. Y.; Hu, W.; Doyle, M. P. J. Org. Chem. 2013, 78, 1583.

(7) For representative papers, see: (a) Felding, J.; Kristensen, J.; Bjerregaard, T.; Sander, L.; Vedsø, P.; Begtrup, M. J. Org. Chem. 1999, 64, 4196. (b) Antilla, J. C.; Baskin, J. M.; Barder, T. E.; Buchwald, S. L. J. Org. Chem. 2004, 69, 5578. (c) Cristau, H.-J.; Cellier, P. P.; Spindler, J.-F.; Taillefer, M. 
Eur. J. Org. Chem. 2004, 695. (d) Mukherjee, A.; Sarkar, A. Tetrahedron Lett. 2004, 45, 9525. (e) Zhu, L.; Guo, P.; Li, G.; Lan, J.; Xie, R.; You, J. J. Org. Chem. 2007, 72, 8535. (f) Xi, Z.; Liu, F.; Zhou, Y.; Chen, W. Tetrahedron 2008, 64, 4254. (g) McLaughlin, M.; Marcantonio, K.; Chen, C. Y.; Davies, I. W. J. Org. Chem. 2008, 73, 4309.

(h) Despotopoulou, C.; Klier, L.; Knochel, P. Org. Lett. 2009, 11, 3326. (i) Goikhman, R.; Jacques, T. L.; Sames, D. J. Am. Chem. Soc. 2009, 131, 3042. (j) Deng, X.; Roessler, A.; Brdar, I.; Faessler, R.; Wu, J.; Sales, Z. S.; Mani, N. S. J. Org. Chem. 2011, 76, 8262.

(8) To our knowledge, only one paper has been reported on the synthesis of tetrasubstituted pyrazoles from the $\mathrm{Cu}$-mediated reaction of enaminones with nitriles using the oxidative strategy, in which $1.5-6$ equiv of $\mathrm{Cu}(\mathrm{OAc}) 2$ were used as both a Lewis acid activator and as an oxidizing agent, and two new bonds, a $\mathrm{C}-\mathrm{C}$ bond and a $\mathrm{C}-\mathrm{N}$ bond, were formed; see: Neumann, J. J.; Suri, M.; Glorius, F. Angew. Chem. Int. Ed. 2010, 49, 7790 .

(9) Although few papers on the $\mathrm{N}-\mathrm{N}$ single bond oxidative formations have been reported, $\mathrm{Ni}$-catalyzed oxidative formation of the $\mathrm{N}-\mathrm{N}$ single bond remains an unexploited area. LDA $/ \mathrm{O}_{2}$ : (a) Barbieri, A.; Montevecchi, P. C.; Nanni, D.; Navacchia, M. L. Tetrahedron 1996, 52, 13255. Cu/air: (b) Kauffmann, T.; Sahm, W. Angew. Chem. Int. Ed. 1967, 6, 85. (c) Kauffmann, T.; Albrecht, J.; Berger, D.; Legler, J. Angew. Chem. Int. Ed. 1967, 6, 633. (d) Ueda, S.; Nagasawa, H. J. Am. Chem. Soc. 2009, 131, 15080. $\mathrm{PbO}_{2}$ or $\mathrm{KMnO}_{4}$ : (e) Wieland, H.; Gambarjan, S. Ber. 1906, 39, 1499.

(f) Windaus, A. Ann. Chem. 1957, 604, 251. $\mathrm{PhI}(\mathrm{III})\left(\mathrm{CF}_{3} \mathrm{CO}_{2}\right)_{2}$ : (g) Correa, A.; Tellitu, I.; Domínguez, E.; SanMartin, R. J. Org. Chem. 2006, 71, 3501. Iron(IV)Oxo complex: (h) Nehru, K.; Jang, Y. K.; Seo, M. S.; Nam, W.; Kim, J. Bull. Korean Chem. Soc. 2007, 28, 843. $\mathrm{NO}_{2}$ : (i) Naimi-Jamal, M. R.; Hamzeali, H.; Mokhtari, J.; Boy, J.; Kaupp, G. ChemSusChem 2009, 2, 83.

(10) Typical Experimental Procedure for the Ni-Catalyzed Cyclotrimerization of $\alpha$-Amino Arylketones: To a
Schlenk tube were added $\alpha$-amino arylketones $\mathbf{1}(0.3 \mathrm{mmol})$, $\left(\mathrm{C}_{5} \mathrm{H}_{5}\right) \mathrm{Ni}(\mathrm{II}) \mathrm{Cl}\left(\mathrm{PPh}_{3}\right)(5 \mathrm{~mol} \%), \mathrm{PhCOOH}$ (1 equiv) and DCE $\left(\mathrm{CH}_{2} \mathrm{ClCH}_{2} \mathrm{Cl}, 2 \mathrm{~mL}\right)$. Then the tube was sealed under air and stirred at $80{ }^{\circ} \mathrm{C}$ (the temperature of the heating bath) for the indicated time until complete consumption of the starting material as monitored by TLC and GC-MS analysis . After the reaction was finished, the reaction mixture was diluted with $\mathrm{Et}_{2} \mathrm{O}$, filtered by a short crude silica gel column and concentrated in vacuum, and the resulting residue was purified by silica gel column chromatography (hexaneEtOAc) to afford the desired product 2.

(Z)-(5-Benzylidene-1,2-diphenyl-2,5-dihydro-1 $\mathrm{H}$ pyrazole-3,4-diyl)bis(phenylmethanone) (2a): Yellow solid: $38.9 \mathrm{mg}, 75 \%$ yield; $\mathrm{mp} 190.2-191.5^{\circ} \mathrm{C}$

(uncorrected). ${ }^{1} \mathrm{H}$ NMR $\left(500 \mathrm{MHz}, \mathrm{CDCl}_{3}\right): \delta=8.11(\mathrm{~d}, J=$ $7.4 \mathrm{~Hz}, 1 \mathrm{H}), 7.47(\mathrm{t}, J=7.7 \mathrm{~Hz}, 1 \mathrm{H}), 7.21-7.32(\mathrm{~m}, 13 \mathrm{H})$, $7.09(\mathrm{td}, J=7.3,4.0 \mathrm{~Hz}, 7 \mathrm{H}), 6.92-6.95(\mathrm{~m}, 2 \mathrm{H}), 6.59-6.62$ $(\mathrm{d}, J=8.5 \mathrm{~Hz}, 2 \mathrm{H}) .{ }^{13} \mathrm{C} \mathrm{NMR}\left(125 \mathrm{MHz}, \mathrm{CDCl}_{3}\right): \delta=191.9$, 186.3, 144.0, 139.1, 138.7, 136.8, 132.6, 132.5, 131.4, $131.2,130.9,129.2,128.7,128.1,127.9,127.7,127.5$, $127.4,127.0,126.9,126.8,126.6,125.3,122.8,120.0$, 114.2. IR (neat): $1715,1593,1448,1363,1223,958,804$, $736,690 \mathrm{~cm}^{-1}$. LRMS (EI, $\left.70 \mathrm{eV}\right): m / z(\%)=518\left[\mathrm{M}^{+}\right](100)$, 295 (94). HRMS (ESI): $m / z[\mathrm{M}+\mathrm{H}]^{+}$calcd for $\mathrm{C}_{36} \mathrm{H}_{26} \mathrm{~N}_{2} \mathrm{O}_{2}$ : 519.2067; found: 519.2089 .

(11) (a) Fanshawe, W. J.; Bauer, V. J.; Safir, S. R. J. Med. Chem. 1972, 15, 980. (b) Ernst, G. E.; Frietze, W. E.; Simpson, T. R. PCT Int. Appl WO2006068591, 2006; Chem. Abstr., 2006, 145,103669

(12) See the data in detail in Supporting Information (Figures S1 and S2 and Schemes S1 and S2).

(13) For paper on the effect of a hydrogen donor (such as benzoic acid), see: (a) Ren, H.; Wulff, W. D. J. Am. Chem. Soc. 2011, 133, 5656. (b) Ren, H.; Wulff, W. D. Org. Lett. 2013, 15, 242. (c) Azap, C.; Rueping, M. Angew. Chem. Int. Ed. 2006, 45, 7832. (d) Zheng, L.-S.; Li, L.; Yang, K.-F.; Zheng, Z.-J.; Xiao, X.-Q.; Xu, L.-W. Tetrahedron 2013, 69, 8777. 